\title{
Correlations between selected quality and electrical parameters of musts from stone and pome fruits
}

\author{
Ryszard Żywica ${ }^{1} \cdot$ Joanna K. Banach ${ }^{1}$ (1)
}

Received: 15 October 2018 / Accepted: 4 February 2019 / Published online: 15 February 2019

(c) The Author(s) 2019

\begin{abstract}
The aim of the research was to determine a correlation between the basic physicochemical quality parameters of musts from selected stone (plums, cherries) and pome (apples, pears) fruits and their electrical parameters-conductivity and capacitance ones. The results of the measurements and their statistical analysis showed strong correlations $(p \leq 0.01)$ between the $\mathrm{Z}$ (impedance) and $\mathrm{Y}$ (admittance) values measured at the frequency of $100 \mathrm{~Hz}$ and acidity values of pome and stone fruits as well as between their $\mathrm{Z}$ and $\mathrm{pH}$ values $(\mathrm{p} \leq 0.05$ ). High correlation coefficients (from -0.765 to -0.874 ) were also obtained between the $\mathrm{Z}$ and $\mathrm{Y}$ values and density and ash content as well as between $\mathrm{Y}$ and $\mathrm{pH}$ values $(-0.870)$ of the analyzed musts. They also showed strong correlations $(\mathrm{p} \leq 0.01)$ between the $\mathrm{C}_{\mathrm{s}}$ (series equivalent capacitance) and $\mathrm{C}_{\mathrm{p}}$ (parallel equivalent capacitance) values measured at $\mathrm{f}=100 \mathrm{~Hz}$ and pectin content and acidity as well as between $\mathrm{C}_{\mathrm{p}}$ values measured at $\mathrm{f}=100 \mathrm{kHz}$ and $\mathrm{f}=100 \mathrm{~Hz}(\mathrm{p} \leq 0.05)$ and contents of dry matter and ash, viscosity, and $\mathrm{pH}$ values of the studied musts. It was found that the results indicate the possibility of describing these correlations with mathematical equations, which in the future may form grounds for the development of a novel, rapid, and simple method for quality assessment of naturally cloudy juices, as an alternative to the standard methods.
\end{abstract}

Keywords Fruit musts · Quality $\cdot$ Physicochemical and electrical parameters $\cdot$ Correlations

\section{Introduction}

An increase in consumer awareness concerning the role of food constituents in body functions makes that they perceive fruit juices and beverages as essential products of their diet. These products owe this special role to their biologically-active compounds. From the nutritional perspective, naturally cloudy juices_- purees and musts, represent significantly richer sources of bioactive compounds compared to the clear juices due to particles of fruit pulp they contain [1, 2]. Significant complexity and time-consumption of methods used to evaluate technological parameters of food products as well as the need for automation of production processes have contributed to a growing interest of scientists in novel methods whose food quality prediction precision would be close to the precision of methods used for direct quality

Joanna K. Banach

katarzyna.banach@uwm.edu.pl

1 Department of Commodity Science, Faculty of Economics, University of Warmia and Mazury in Olsztyn, Pl. Cieszynski 1, 10-975 Olsztyn, Poland measurement. In addition, predictions derived from those methods would be correlated with changes in the chemical composition (water, high- and low-molecular compounds) and structure of food products during their production process as well as with changes in the degree of electrolyte dissociation in the examined biological material [3-5]. Hence investigations on the use of electrical properties, including: conductivity properties typical of such food products as: milk, fruit juices, and alcohols [6-8] and dielectrical properties typical of such food items as: butter, vegetable oils, animal fats, cheeses, etc., have been inscribing into these research interests.

Today's advance in the direct and indirect methods for impedance measurement focuses on the quantitation and identification of certain groups of bacteria in milk and dairy products, meat, fish, frozen vegetables, cereal products, confectionery products, and also yeast in fruit juices and wine [9-11]. Advisability of these measures is confirmed by a positive correlation demonstrated by Fernández et al. [12] between the traditional microbiological method and the indirect impedance method. In addition, a strong correlation shown between results of mechanical assays and 
electrical parameters of fruits (nectarines, kiwi, apples) and vegetables (tomatoes) has proved the usability of plant tissues impedance measurements as indicators of their freshness, ripeness, and their mechanical and storage damages [13-17]. Impedance measurements may also prove well in the assessment of moisture content during the heating and drying of potato tubers and carrot roots, and in the detection of artificial chemical additives in liquid food products [18-20]. The results of our own studies showed that measurements of electrical parameters (impedance, resistance, admittance, and conductance) may be applied to assess apple puree concentrations in pulpy juices and beverages $[2,21]$, to determine contents of Total Soluble Solids (TSS) in reconstituted apple juices [22], and to determine contents of mineral substances, ash, and dry matter in apple juice [8].

Considering the above, a study was undertaken with the aim to determine a correlation between the basic physicochemical quality parameters of musts from selected stone and pome fruits and their electrical parameters-conductivity and capacitance ones.

\section{Materials and methods}

The experimental material included fruit musts from fresh apples and pears, and from frozen cherries and plums from orchard cultivations in Poland. Apples and pears without cores were cut into pieces by means of the Fenomen 880.0 food-processor (Zelmer, Poland), equipped with a rotary knife, next smashed in the MZ-80/R mechanical and colloidal grinder (Fryma, Germany) and pressed through the WP 30 HPM hydraulic press, model 30t DL (Dema, Germany) with the pressure of $75 \mathrm{kG} / \mathrm{cm}^{2}$. To separate residues from solid particles, the musts were centrifuged in the GS-6R centrifuge (Beckman, Germany) for $10 \mathrm{~min}$ at $1200 \mathrm{rpm}$. Defrosted plums and cherries had their stones removed, and were pre-pressed in the above-mentioned food-processor (Zelmer, Poland). The further process of must preparation from plums and cherries was analogous to that conducted for apples and pears. The experimental material (ca. 0.7L) was transferred to containers and stored in the frozen state (ca. $-25^{\circ} \mathrm{C}$ ) until analyzed (ca. 2 weeks).

\section{Physicochemical analyses}

Physicochemical parameters of fruit musts were analyzed accordingly to the Polish Standard (PN-90/A-7510). These analyses included the following determinations and measurements:

- total soluble solids content and refractometric index, with the refractometric method [23],

- organic acid content, with the titration method [24],
- density, with the pycnometric method [25],

- active acidity, using a Piccolo pH-meter by HANNA [26],

- dry matter content, with the drying method [27],

- mineral content (ash), with the incineration method [28],

- pectin content $-25 \mathrm{~cm}^{3}$ were collected from a mixed and homogenized sample of musts to a beaker, then $50 \mathrm{~cm}^{3}$ of acetone were added, and the mixture was left for ca. $1 \mathrm{~h}$ for precipitation. The resultant precipitate was filtered through the earlier dried and weighed filter $\left(\mathrm{M}_{1}\right)$. Afterwards, the filter together with the precipitate was dried at $95{ }^{\circ} \mathrm{C}$ for $30 \mathrm{~min}$ and weighed again $\left(\mathrm{M}_{2}\right)$. The result was obtained from mass difference $\left(\mathrm{M}_{2}-\mathrm{M}_{1}\right)$ and then by expressing this difference per $100 \mathrm{~cm}^{3}$ [29].

- viscosity, with the rotary rheometer Rheotest-2 (Rheotest Medingen, Germany), according to the procedure give in its operating instructions. The measurements were conducted using the $\mathrm{S} 2$ cylinder at the sample temperature of $20 \pm 1{ }^{\circ} \mathrm{C}$ and the shear rate of $100 \mathrm{~s}^{-1}$. The viscosity of musts were calculated on the basis of the measured angle coefficient $(\alpha)$, according to the equation:

$\eta[\mathrm{Pas}]=\mathrm{Z} \alpha / 10 \mathrm{D}_{\mathrm{r}}$

where: $\mathrm{D}_{\mathrm{r}}$ - shear rate $\left[\mathrm{s}^{-1}\right], \mathrm{Z}$-device constant 24,428 [dyn $\left./ \mathrm{cm}^{2}\right]$.

\section{Measurements of electrical parameters}

Before measurements, the samples were kept in the climatic chamber (Memmert, USA) at air temperature of $20 \pm 0.1{ }^{\circ} \mathrm{C}$ for $24 \mathrm{~h}$. Once the desired temperature has been achieved in the samples, $200 \mathrm{~cm}^{3}$ of the sample was poured into an ownconstruction glass container $(75 \times 55 \times 94 \mathrm{~mm})$ equipped in two plate electrodes made of stainless steel which were attached to the two opposite smaller walls of the container. Afterwards, the container was placed in a thermostat system (an own-construction container with a water jacket + thermostat, by (PolyScience, USA) to which a measuring attachment was coupled (the attachment was part of an HP 4263B meter by Agilent, USA). The RCC food model, adopted in our previous investigations [2,21], was then used to measure: impedance $(\mathrm{Z})$, admittance $(\mathrm{Y})$, parallel equivalent capacitance $\left(\mathrm{C}_{\mathrm{p}}\right)$, and series equivalent capacitance $\left(\mathrm{C}_{\mathrm{s}}\right)$, at the voltage of $200 \mathrm{mV}$ and frequencies ranging from $100 \mathrm{~Hz}$ to $100 \mathrm{kHz}$. The measurements were carried out in 5 replications for each sample.

\section{Statistical analysis}

The statistical analysis of obtained data was performed using Statistica 12 (StatSoft Inc.) software. The results of analyzes were presented as means ${ }^{ \pm}$standard deviations. The analysis of variance Duncan's Multiple Comparison Test were 
reported on the following levels of significance $p \leq 0.05$ and $\mathrm{p} \leq 0.01$. Correlation were calculated to determine the relation between selected physicochemical distinguishing features of quality of: apples, pears, plums and cherries musts, and their conductivity and capacity electrical parameters, made in the frequency $100 \mathrm{~Hz}$ and $100 \mathrm{kHz}$. The results of statistical analyzes were presented as correlation coefficient (r) and level of significance calculated (p).

\section{Results and discussion}

Results of determinations and measurements of the major physicochemical quality parameters of musts from the selected pome and stone fruits demonstrated the plum must to be characterized by the highest contents of: dry matter $(12.62 \mathrm{~g} / 100 \mathrm{~g})$, TSS $(13.3 \mathrm{~g} / 100 \mathrm{~g})$, and ash $(0.92 \mathrm{~g} / 100 \mathrm{~g})$. Also its density was the highest among all analyzed musts and reached $1.055 \mathrm{~g} / \mathrm{cm}^{3}$. In contrast, this must had the lowest viscosity, accounting for 0.054 Pascal. The lowest contents of dry matter $(7.68 \mathrm{~g} / 100 \mathrm{~g})$ and TSS $(11.1 \mathrm{~g} / 100 \mathrm{~g})$ as well as the lowest values of density $\left(1.040 \mathrm{~g} / \mathrm{cm}^{3}\right)$ and acidity $(0.268 \mathrm{~g} / 100 \mathrm{~g})$ were determined for the pear must. This must was, additionally, characterized by the highest $\mathrm{pH}$ and viscosity values which reached 4.28 and 0.207 Pascal, respectively. The musts from cherries had the highest acidity value $(1.474 \mathrm{~g} / 100 \mathrm{~g})$ and the lowest $\mathrm{pH}$ value (3.16) and pectin content $(0.79 \mathrm{~g} / 100 \mathrm{~g})$. In turn, apple musts were characterized by the highest pectin content $(2.57 \mathrm{~g} / 100 \mathrm{~g})$ and by the lowest ash content $(0.08 \mathrm{~g} / 100 \mathrm{~g})$. Results of the other physicochemical determinations and measurements of musts from pome and stone fruits fitted within the abovepresented ranges of values. The statistical analysis of the results of measurements and determinations demonstrated significant $(\mathrm{p} \leq 0.01 ; \mathrm{p} \leq 0.05)$ differences between values of all physicochemical parameters of the pome fruits: applespears, and of the stone fruits: plums-cherries. Significant $(p \leq 0.01 ; p \leq 0.05)$ differences were also shown between values of all physicochemical parameters of the majority of pome and stone fruits, regardless of fruit type, i.e. in total (Table 1).

Results of conductivity measurements of electrical parameters $(\mathrm{Z}, \mathrm{Y})$ of the analyzed musts demonstrated their values to differ significantly depending on fruit type, and to differ inconsiderably depending on the frequency of the measuring voltage. The highest values of impedance $(Z)$ and simultaneously the lowest values of admittance (Y) at the frequency of $100 \mathrm{~Hz}$ (ca. $182 \Omega$ and ca. $5.5 \mathrm{mS}$ ) were demonstrated for the must from pears, whereas the lowest $Z$ values (ca. $113 \Omega$ ) and the highest $Y$ values (ca. $8.9 \mathrm{mS}$ ) were found for the cherry must. These results indicate that cherry musts were characterized by the best electrical conductivity among all studied musts from both pome and stone fruits.
Table 1 Selected physicochemical distinguishing features of quality of apples, pears, plums and cherries musts

\begin{tabular}{llllll}
\hline Physicochemical parameters & \multicolumn{3}{l}{$\begin{array}{l}\text { Musts from pome } \\
\text { fruits }\end{array}$} & & \multicolumn{2}{l}{$\begin{array}{l}\text { Musts from stone } \\
\text { fruits }\end{array}$} \\
\cline { 2 - 3 } \cline { 6 - 6 } \cline { 5 - 6 } & Apple & Pears & & Plums & Cherries \\
\hline Dry matter [g/100g] & $9.62^{\mathrm{b}}$ & $7.68^{\mathrm{c}}$ & & $12.62^{\mathrm{a}}$ & $9.55^{\mathrm{b}}$ \\
Total soluble solids [g/100g] & $12.8^{\mathrm{B}}$ & $11.1^{\mathrm{c}}$ & & $13.3^{\mathrm{A}}$ & $11.9^{\mathrm{c}}$ \\
Ash [g/100g] & $0.08^{\mathrm{d}}$ & $0.10^{\mathrm{c}}$ & & $0.92^{\mathrm{A}}$ & $0.81^{\mathrm{B}}$ \\
Acidity [g/100g] & $0.971^{\mathrm{c}}$ & $0.268^{\mathrm{d}}$ & & $1.106^{\mathrm{b}}$ & $1.474^{\mathrm{a}}$ \\
Viscosity [Pascal] & $0.169^{\mathrm{b}}$ & $0.207^{\mathrm{a}}$ & & $0.054^{\mathrm{c}}$ & $0.162^{\mathrm{b}}$ \\
Density [g/cm $\left.{ }^{3}\right]$ & $1.051^{\mathrm{a}}$ & $1.040^{\mathrm{c}}$ & & $1.055^{\mathrm{b}}$ & $1.052^{\mathrm{a}}$ \\
pH & $3.30^{\mathrm{b}}$ & $4.28^{\mathrm{a}}$ & & $3.23^{\mathrm{b}}$ & $3.16^{\mathrm{b}}$ \\
Pectin [g/100g] & $2.57^{\mathrm{a}}$ & $1.43^{\mathrm{c}}$ & & $2.18^{\mathrm{b}}$ & $0.79^{\mathrm{d}}$ \\
\hline
\end{tabular}

${ }^{\mathrm{a}-\mathrm{d}}$ Mean values in columns indicated with various small letters are statistically significantly different at $\mathrm{p} \leq 0.01$

${ }^{\mathrm{A}-\mathrm{B}}$ Mean values in columns indicated with various capital letter are statistically significantly different at $\mathrm{p} \leq 0.05$

Differences between $\mathrm{Z}$ values measured at the frequency of $100 \mathrm{~Hz}$ and these measured at the frequency of $100 \mathrm{kHz}$ reached ca. $2 \Omega$, whereas respective differences between $\mathrm{Y}$ values accounted for ca. $0.12 \mathrm{mS}$ (Table 2).

Results of capacitance measurements of electrical parameters of fruit musts demonstrated their values to be largely differentiated depending on both fruit type and frequency of the test voltage. The highest values of the parallel equivalent capacitance $\left(\mathrm{C}_{\mathrm{p}}\right)$ and the series equivalent capacitance $\left(\mathrm{C}_{\mathrm{s}}\right)$ were demonstrated for the cherry musts $(558.69 \mathrm{nF}$ and $357.72 \mu \mathrm{F}$, respectively). In contrast, the lowest $\mathrm{C}_{\mathrm{p}}$ and $\mathrm{C}_{\mathrm{s}}$ values, measured at the frequency of $100 \mathrm{~Hz}(222.82 \mathrm{nF}$ and $312.35 \mu \mathrm{F}$, respectively), were found for the musts from pears and apples. An increase in the frequency of the test voltage resulted in a significant decrease in $C_{p}$ and $C_{s}$ values of all studied musts. Significant $(\mathrm{p} \leq 0.01)$ tendencies of changes in $\mathrm{C}_{\mathrm{p}}$ and $\mathrm{C}_{\mathrm{s}}$ values of each must in the function of voltage frequency indicate that also frequency should be taken into consideration in future studies on the use of capacitance properties (Table 2).

The analysis of results of measurements of the electrical parameters of pome fruits (apples and pears) and stone fruits (cherries and plums) revealed that the impedance $(\mathrm{Z})$ values of musts from the pome fruits were significantly higher from these of the stone fruits. In turn, opposite dependencies were observed for the admittance $(\mathrm{Y})$ values of the analyzed musts. Likewise the $\mathrm{Y}$ values, the $\mathrm{C}_{\mathrm{p}}$ values of the musts from apples and pear were significantly lower from the $C_{p}$ values of the musts from cherries and plums. Respective differences between $\mathrm{C}_{\mathrm{s}}$ values determined for the musts from stone and pome fruits were significantly smaller (Table 2 ).

The statistical analysis of the results of measurements of the conductivity parameters of the pome and stone fruits 
Table 2 Results of measurement (mean values \pm standard deviation) conductivity $(\mathrm{Z}, \mathrm{Y})$ and capacity $\left(\mathrm{C}_{\mathrm{p}}, \mathrm{C}_{\mathrm{s}}\right)$ parameters of apples, pears, plums and cherries musts, made in the frequency range from $100 \mathrm{~Hz}$ to $100 \mathrm{kHz}$

\begin{tabular}{llllll}
\hline $\begin{array}{l}\text { Electrical param- } \\
\text { eters / frequency }\end{array}$ & Fruits musts & $\mathrm{Z}[\Omega]$ & $\mathrm{Y}[\mathrm{mS}]$ & $\mathrm{C}_{\mathrm{p}}[\mathrm{nF}]$ & $\mathrm{C}_{\mathrm{s}}[\mu \mathrm{F}]$ \\
\hline $\mathrm{f}=100 \mathrm{~Hz}$ & Apples & $144.76 \pm 0.60^{\mathrm{b}}$ & $6.910 \pm 0.03^{\mathrm{c}}$ & $388.05 \pm 18.36^{\mathrm{c}}$ & $312.35 \pm 16.6^{\mathrm{c}}$ \\
& Pears & $182.14 \pm 1.13^{\mathrm{a}}$ & $5.494 \pm 0.03^{\mathrm{d}}$ & $222.82 \pm 6.94^{\mathrm{d}}$ & $343.51 \pm 8.47^{\mathrm{b}}$ \\
& Plums & $132.57 \pm 0.37^{\mathrm{c}}$ & $7.545 \pm 0.03^{\mathrm{b}}$ & $453.07 \pm 7.41^{\mathrm{b}}$ & $318.90 \pm 5.69^{\mathrm{c}}$ \\
& Cherries & $112.70 \pm 1.49^{\mathrm{d}}$ & $8.874 \pm 0.12^{\mathrm{a}}$ & $558.69 \pm 16.93^{\mathrm{a}}$ & $357.72 \pm 2.38^{\mathrm{a}}$ \\
$\mathrm{f}=1 \mathrm{kHz}$ & Apples & $143.26 \pm 0.58^{\mathrm{b}}$ & $6.981 \pm 0.03^{\mathrm{c}}$ & $5.902 \pm 0.30^{\mathrm{c}}$ & $206.31 \pm 8.78^{\mathrm{d}}$ \\
& Pears & $180.54 \pm 1.05^{\mathrm{a}}$ & $5.540 \pm 0.03^{\mathrm{d}}$ & $3.447 \pm 0.10^{\mathrm{d}}$ & $221.71 \pm 3.91^{\mathrm{b}}$ \\
& Plums & $131.02 \pm 0.40^{\mathrm{c}}$ & $7.634 \pm 0.02^{\mathrm{b}}$ & $6.842 \pm 0.09^{\mathrm{b}}$ & $216.59 \pm 3.34^{\mathrm{c}}$ \\
$\mathrm{f}=10 \mathrm{kHz}$ & Cherries & $111.20 \pm 1.35^{\mathrm{d}}$ & $8.995 \pm 0.11^{\mathrm{a}}$ & $8.535 \pm 0.17^{\mathrm{a}}$ & $240.35 \pm 1.47^{\mathrm{a}}$ \\
& Apples & $142,96 \pm 0.57^{\mathrm{b}}$ & $6.996 \pm 0.03^{\mathrm{c}}$ & $0.118 \pm 0.01^{\mathrm{c}}$ & $106.14 \pm 2.68^{\mathrm{C}}$ \\
& Pears & $180.17 \pm 1.03^{\mathrm{a}}$ & $5.551 \pm 0.03^{\mathrm{d}}$ & $0.075 \pm 0.00^{\mathrm{d}}$ & $103.79 \pm 1.13^{\mathrm{d}}$ \\
& Plums & $130.66 \pm 0.39^{\mathrm{c}}$ & $7.655 \pm 0.02^{\mathrm{b}}$ & $0.137 \pm 0.00^{\mathrm{b}}$ & $108.68 \pm 1.27^{\mathrm{bB}}$ \\
$\mathrm{f}=100 \mathrm{kHz}$ & Cherries & $110.85 \pm 1.31^{\mathrm{d}}$ & $9.024 \pm 0.11^{\mathrm{a}}$ & $0.164 \pm 0.00^{\mathrm{a}}$ & $122.64 \pm 4.50^{\mathrm{a}}$ \\
& Apples & $142.80 \pm 0.58^{\mathrm{b}}$ & $7.003 \pm 0.03^{\mathrm{c}}$ & $0.019 \pm 0.00^{\mathrm{c}}$ & $6.722 \pm 0.68^{\mathrm{b}}$ \\
& Pears & $180.01 \pm 0.99^{\mathrm{a}}$ & $5.564 \pm 0.03^{\mathrm{d}}$ & $0.018 \pm 0.00^{\mathrm{d}}$ & $4.427 \pm 0.11^{\mathrm{d}}$ \\
& Plums & $130.47 \pm 0.39^{\mathrm{c}}$ & $7.666 \pm 0.02^{\mathrm{b}}$ & $0.028 \pm 0.00^{\mathrm{a}}$ & $5.409 \pm 0.10^{\mathrm{c}}$ \\
& Cherries & $110.61 \pm 1.27^{\mathrm{d}}$ & $9.044 \pm 0.10^{\mathrm{a}}$ & $0.024 \pm 0.00^{\mathrm{b}}$ & $8.697 \pm 0.56^{\mathrm{a}}$ \\
\hline
\end{tabular}

$Z$ impedance, $Y$ admittance, $C_{p}$ parallel equivalent capacitance, $C_{s}$ series equivalent capacitance

${ }^{\mathrm{a}-\mathrm{d}}$ Mean value in columns with different small letters differ significantly at $\mathrm{p} \leq 0.01$

${ }^{\mathrm{A}-\mathrm{B}}$ Mean value in columns with different capital letters differ significantly at $\mathrm{p} \leq 0.05$ in the function of the frequency of the test voltage demonstrated significant $(\mathrm{p} \leq 0.01)$ differences between $\mathrm{Z}$ and $Y$ values measured for the musts from apples and pears at the frequency of $100 \mathrm{~Hz}$ and the values of these parameters measured at the frequencies of 1,10 , and $100 \mathrm{kHz}$. Significant $(\mathrm{p} \leq 0.05)$ differences were also obtained between the $\mathrm{Z}$ and $\mathrm{Y}$ values of musts from pears measured at the frequency of $100 \mathrm{~Hz}$ and their values measured at the frequencies of 1,10 , and $100 \mathrm{kHz}$ as well as between $\mathrm{Z}$ and $\mathrm{Y}$ values of cherry musts measured at the frequencies of 10 and $100 \mathrm{kHz}$. In contrast, no significant differences were found between the $\mathrm{Z}$ and $\mathrm{Y}$ values of the musts from pome and stone fruits measured in a frequency range from 1 to $100 \mathrm{kHz}$ (Table 3).

Results of statistical calculations made for capacitance parameters of pome and stone fruits in the function of measuring voltage frequency demonstrated significant $(\mathrm{p} \leq 0.01)$ differences between the $\mathrm{C}_{\mathrm{p}}$ and $\mathrm{C}_{\mathrm{s}}$ values of the musts from

Table 3 Statistical analysis of the effect of the frequency of the test voltage on changes in $\mathrm{Z}, \mathrm{Y}, \mathrm{C}_{\mathrm{p}}$, and $\mathrm{C}_{\mathrm{s}}$ values of musts from pome and stone fruits

\begin{tabular}{|c|c|c|c|c|c|c|c|c|c|c|c|c|c|}
\hline & \multirow[t]{3}{*}{ Frequency } & \multicolumn{12}{|l|}{$\mathrm{Z} / \mathrm{Y}$} \\
\hline & & \multicolumn{3}{|l|}{ Apples } & \multicolumn{3}{|l|}{ Pears } & \multicolumn{3}{|l|}{ Plums } & \multicolumn{3}{|l|}{ Cherries } \\
\hline & & $100 \mathrm{~Hz}$ & $1 \mathrm{kHz}$ & $10 \mathrm{kHz}$ & $100 \mathrm{~Hz}$ & $1 \mathrm{kHz}$ & $10 \mathrm{kHz}$ & $100 \mathrm{~Hz}$ & $1 \mathrm{kHz}$ & $10 \mathrm{kHz}$ & $100 \mathrm{~Hz}$ & $1 \mathrm{kHz}$ & $10 \mathrm{kHz}$ \\
\hline \multirow{4}{*}{$\begin{array}{l}\text { Z/Y } \\
\text { Apples } \\
\text { Pears } \\
\text { Plums } \\
\text { Cherries }\end{array}$} & $1 \mathrm{kHz}$ & $* *$ & - & - & $* *$ & - & - & $*$ & - & - & NS & - & - \\
\hline & $10 \mathrm{kHz}$ & $* *$ & NS & - & $* *$ & NS & - & $*$ & NS & - & NS & NS & - \\
\hline & $100 \mathrm{kHz}$ & $* *$ & NS & NS & $* *$ & NS & NS & $*$ & NS & NS & $*$ & NS & NS \\
\hline & & $\mathrm{Cp} / \mathrm{Cs}$ & & & & & & & & & & & \\
\hline $\mathrm{Cp} / \mathrm{Cs}$ & $1 \mathrm{kHz}$ & $* *$ & - & - & $* *$ & - & - & $* *$ & - & - & $* *$ & - & - \\
\hline Apples & $10 \mathrm{kHz}$ & $* *$ & $* *$ & - & $* *$ & $* *$ & - & $* *$ & $* *$ & - & $* *$ & $* *$ & - \\
\hline $\begin{array}{l}\text { Pears } \\
\text { Plums } \\
\text { Cherries }\end{array}$ & $100 \mathrm{kHz}$ & $* *$ & $* *$ & $* *$ & $* *$ & $* *$ & $* *$ & $* *$ & $* *$ & $* *$ & $* *$ & $* *$ & $* *$ \\
\hline
\end{tabular}

NS non significant

**significance level $\mathrm{p}<0.01 ;$ *significance level $\mathrm{p}<0.05$ 
pome and stone fruits measured in a frequency range from $100 \mathrm{~Hz}$ to $100 \mathrm{kHz}$ (Table 3).

The statistical analysis of the results of measurements of the conductivity parameters showed strong correlations $(\mathrm{p} \leq 0.01)$ between the $\mathrm{Z}$ and $\mathrm{Y}$ values measured at the frequency of $100 \mathrm{~Hz}$ and acidity values of pome and stone fruits as well as between their $\mathrm{Z}$ and $\mathrm{pH}$ values $(\mathrm{p} \leq 0.05)$. High correlation coefficients (from -0.765 to -0.874 ) were also obtained between the $\mathrm{Z}$ and $\mathrm{Y}$ values and density and ash content as well as between $\mathrm{Y}$ and $\mathrm{pH}$ values $(-0.870)$ of the analyzed musts (Table 4.).

Results of statistical calculations made for the capacitance parameters also demonstrated strong correlations $(p \leq 0.01)$ between the $\mathrm{C}_{\mathrm{s}}$ and $\mathrm{C}_{\mathrm{p}}$ values measured at $\mathrm{f}=100 \mathrm{~Hz}$ and pectin content and acidity as well as between $\mathrm{C}_{\mathrm{p}}$ values measured at $\mathrm{f}=100 \mathrm{kHz}$ and $\mathrm{f}=100 \mathrm{~Hz}(\mathrm{p} \leq 0.05)$ and contents of dry matter and ash, viscosity, and $\mathrm{pH}$ values of the studied musts. High correlation coefficients (0.654-0.802) were also obtained between $\mathrm{C}_{\mathrm{p}}$ values $(\mathrm{f}=100 \mathrm{kHz})$ and density, $\mathrm{pH}$, acidity, and TSS content as well as between $\mathrm{C}_{\mathrm{s}}$ values $(\mathrm{f}=100 \mathrm{kHz})$ and acidity and $\mathrm{pH}$ values $(0.866$ and $-0.725)$, and also between $\mathrm{C}_{\mathrm{s}}$ values $(\mathrm{f}=100 \mathrm{~Hz})$ and TSS content (-0.758) of the analyzed musts (Table 4).

A comparative analysis of our results of impedance (Z) measurements conducted for the musts from both pome and stone fruits with results of impedance measurements performed for purees from the same fruits [22] revealed that the $\mathrm{Z}$ values of musts were significantly lower than these of purees. In turn, values of admittance-likewise these of $\mathrm{C}_{\mathrm{p}}$-of the musts from the analyzed fruits were considerably higher from the respectively values obtained for the purees. This indicates that the pressing process followed by centrifugation process contributed to an improvement in the electrical conductivity and to an increase in the capacitance of the musts obtained from pome and stone fruits. This is due to an increase in the number and motility of small ions, like: $\mathrm{K}^{+}$, $\mathrm{Na}^{+}, \mathrm{Ca}^{2+}$ or $\mathrm{Mg}^{2+}$, as a result of removing solid particles which weaken the external electrical field and inhibit the hydrodynamic movement of fast ions, thereby minimizing the possibility of their movement in the electrical field [30, 31]. The significant differences in the values of the electrical parameters $\left(\mathrm{Z}, \mathrm{Y}, \mathrm{C}_{\mathrm{p}} \mathrm{C}_{\mathrm{s}}\right)$ between fruit musts and purees [22] point to the possibility of approaching a new direction in the studies on the use of these parameters in the quality assessment and identification of fruit juices and fruit purees.

Correlations obtained between the basic physicochemical quality attributes of musts from selected pome and stone fruits and their electrical conductance $(\mathrm{Z}, \mathrm{Y})$ and capacitance $\left(\mathrm{C}_{\mathrm{s}}, \mathrm{C}_{\mathrm{p}}\right)$ justify the choice of the RCC model for investigating their electrical properties. Also the results of studies conducted by Żywica et al. [32] and by Banach et al. [33] with the use of the RCC model, demonstrated correlations between the fat content in raw milk and between the rapeseed oil content in fat blends and their electrical parameters.
Table 4 Correlations between physicochemical quality parameters of musts from pome fruits (apples and pears) and stone fruits (plums and cherries) and their electrical parameters measured at selected frequencies $-100 \mathrm{~Hz}$ and $100 \mathrm{kHz}$

\begin{tabular}{|c|c|c|c|c|c|c|c|}
\hline \multicolumn{2}{|c|}{$\begin{array}{l}\text { Electrical parameters/physicochemi- } \\
\text { cal parameters }\end{array}$} & \multirow{2}{*}{$\begin{array}{c}\mathrm{Z}_{100 \mathrm{~Hz}} \\
-0.587\end{array}$} & \multirow{2}{*}{$\begin{array}{c}\mathrm{Y}_{100 \mathrm{~Hz}} \\
0.564\end{array}$} & \multirow{2}{*}{$\begin{array}{l}\mathrm{Cp}_{100 \mathrm{~Hz}} \\
0.564\end{array}$} & \multirow{2}{*}{$\begin{array}{l}\mathrm{Cp}_{100 \mathrm{kHz}} \\
\mathbf{0 . 9 0 4}\end{array}$} & \multirow{2}{*}{$\begin{array}{c}\mathrm{Cs}_{100 \mathrm{~Hz}} \\
-0.497\end{array}$} & \multirow{2}{*}{$\begin{array}{l}\mathrm{Cs}_{100 \mathrm{kHz}} \\
0.079\end{array}$} \\
\hline Dry matter $[\mathrm{g} / 100 \mathrm{~g}]$ & $\mathrm{r}$ & & & & & & \\
\hline & $\mathrm{p}$ & 0.412 & 0.512 & 0.436 & $\leq \mathbf{0 . 0 5}$ & 0.503 & 0.921 \\
\hline \multirow[t]{2}{*}{ Total Soluble Solids [g/100g] } & $\mathrm{r}$ & -0.520 & 0.479 & 0.478 & 0.654 & -0.758 & 0.110 \\
\hline & $\mathrm{p}$ & 0.480 & 0.624 & 0.521 & 0.346 & 0.242 & 0.890 \\
\hline \multirow[t]{2}{*}{ Ash [g/100g] } & $\mathrm{r}$ & -0.765 & 0.775 & 0.779 & 0.954 & 0.218 & 0.403 \\
\hline & $\mathrm{p}$ & 0.235 & 0.233 & 0.221 & $\leq \mathbf{0 . 0 5}$ & 0.782 & 0.597 \\
\hline \multirow[t]{2}{*}{ Acidity $[\mathrm{g} / 100 \mathrm{~g}]$} & $\mathrm{r}$ & -0.998 & 0.982 & 0.994 & 0.671 & 0.098 & 0.866 \\
\hline & $\mathrm{p}$ & $\leq \mathbf{0 . 0 1}$ & $\leq \mathbf{0 . 0 1}$ & $\leq \mathbf{0 . 0 1}$ & 0.329 & 0.902 & 0.134 \\
\hline \multirow[t]{2}{*}{ Viscosity [Pascal] } & $\mathrm{r}$ & 0.504 & -0.486 & -0.486 & $-0.920 *$ & 0.445 & 0.029 \\
\hline & $\mathrm{p}$ & 0.496 & 0.594 & 0.514 & $\leq \mathbf{0 . 0 5}$ & 0.555 & 0.907 \\
\hline \multirow[t]{2}{*}{ Density $\left[\mathrm{g} / \mathrm{cm}^{3}\right]$} & $\mathrm{r}$ & -0.874 & 0.791 & 0.850 & 0.802 & -0.352 & 0.542 \\
\hline & $\mathrm{p}$ & 0.126 & 0.215 & 0.150 & 0.198 & 0.648 & 0.458 \\
\hline \multirow[t]{2}{*}{$\mathrm{pH}$} & $\mathrm{r}$ & 0.935 & -0.870 & -0.915 & -0.674 & 0.230 & -0.725 \\
\hline & $\mathrm{p}$ & $\leq \mathbf{0 . 0 5}$ & 0.133 & $\leq \mathbf{0 . 0 5}$ & 0.326 & 0.769 & 0.275 \\
\hline \multirow[t]{2}{*}{ Pectin $[\mathrm{g} / 100 \mathrm{~g}]$} & $\mathrm{r}$ & 0.195 & -0.247 & -0.247 & -0.018 & -0.995 & -0.415 \\
\hline & $\mathrm{p}$ & 0.805 & 0.649 & 0.753 & 0.982 & $\leq \mathbf{0 . 0 1}$ & 0.585 \\
\hline \multicolumn{8}{|c|}{$\mathrm{Z}_{100 \mathrm{~Hz}}, \mathrm{Y}_{100 \mathrm{~Hz}}$-impedance $(\mathrm{Z}) \mathrm{i}$ admitance $(\mathrm{Y})$ made in the frequency $100 \mathrm{~Hz}$} \\
\hline \multicolumn{8}{|c|}{$\begin{array}{l}\mathrm{C}_{\mathrm{p} 100 \mathrm{~Hz}}, \mathrm{C}_{\mathrm{s} 100 \mathrm{~Hz}}-\text { parallel equivalent }(\mathrm{Cp}) \text { and series equivalent }\left(\mathrm{C}_{\mathrm{s}}\right) \text { capacitance made in the frequency } \\
100 \mathrm{~Hz} ;\end{array}$} \\
\hline \multicolumn{8}{|c|}{$\mathrm{C}_{\mathrm{p} 100 \mathrm{kHz}}, \mathrm{C}_{\mathrm{s} 100 \mathrm{kHz}}$-parallel equivalent and series equivalent capacitance made in the frequency $100 \mathrm{kHz}$} \\
\hline
\end{tabular}


The RCC model was also used by Mabrook and Petty [34, 35 ] to determine the chemical composition of milk and the degree of its watering. This means that the use of the electrical RCC model in research enables applying exploiting dielectric properties of such biological systems as: butter or fat blends, as well as conductance properties of milk or fruit musts for the quality assessment and prediction. Literature data indicates that physicochemical properties of food products are also studied with the RRC model in whichcompared to the RCC model-the parallel electrical capacitance $\left(C_{p}\right)$ is replaced by parallel resistance $\left(R_{p}\right)$. For this reason, the RRC model reflects the morphology and chemical composition of muscle tissue and is used to determine correlations between electrical parameters (mainly related to the conductance) ones of meat and meat products and their quality attributes [36, 37].

\section{Conclusions}

1. Insignificant differences in the impedance and admittance values of the fruit musts in the function of changes of test voltage frequencies are indicative of their resistance-capacitance character and of the possibility of choosing any frequency within the range from $100 \mathrm{~Hz}$ to $100 \mathrm{kHz}$ for further investigations.

2. The significant correlations $(\mathrm{p} \leq 0.01, \mathrm{p} \leq 0.05)$ obtained between the capacitance parameters and physicochemical quality parameters of the musts from stone and pome fruits point to the possibility of describing these correlations with mathematical equations, which in the future may form grounds for the development of a novel, rapid, and simple method for quality assessment of naturally cloudy juices, as an alternative to the standard (reference) methods.

Open Access This article is distributed under the terms of the Creative Commons Attribution 4.0 International License (http://creativeco mmons.org/licenses/by/4.0/), which permits unrestricted use, distribution, and reproduction in any medium, provided you give appropriate credit to the original author(s) and the source, provide a link to the Creative Commons license, and indicate if changes were made.

\section{References}

1. J. Markowski (1997) Wybrane czynniki warunkujące jakość naturalnie mętnych soków jabłkowych. Przem. Fermentacyjny i Owocowo-Warzywny, (10): 35-39 (in Polish)

2. G. Pierzynowska-Korniak, R. Żywica, J. Wójcik, Electric properties of apple puree and pulpy apple juices. Eur. Food Res. Technol. 216(5), 385-389 (2003)

3. E. Ibañez, A. Cifuentes, New analytical techniques in food science. Crit. Rev. Food Sci. 41(6), 413-450 (2001)
4. K.M. Majewska, J.K. Banach, R. Żywica, I. Białobrzewski (2008) Influence of variety, moisture content, kernel size and applied current frequency on the electric properties of wheat grain. Int. J. Food Prop. (11): 392-406

5. J.K. Banach, K. Majewska, A. Ejsmont, R. Żywica, E. Grabowska, Effect of species, chemical composition and measurement frequency on conductance properties of cereal grains. Pol J Comm Sci 3(52), 49-58 (2017)

6. J.K. Banach, R. Żywica, J. Szpendowski, K. Kiełczewska (2012) Possibilities of using electrical parameters of milk for assessing its adulteration with water. Int. J. Food Prop. (15): 274-280

7. R. Żywica, J.K. Banach, M. Modzelewska-Kapituła, Possibilities of the quality assessment of apple juice concentrate using its equivalent electrical model. Pol. J. Comm. Sci. 4(45), 80-86 (2015)

8. R. Żywica, J.K. Banach, M. Modzelewska-Kapituła, The influence of selected mineral components and dry matter contents on the electrical conductivity of apple juice. Pol. J. Comm. Sci. 3(45), 80-86 (2017)

9. S. Bolliger, M. Casella, M. Teuber, Comparative impedance evaluation of different foodstuffs. LWT-Food Sci. Technol. 27(2), 177-184 (1994)

10. K. Orsi, S. Torriani, B. Battistotti, M. Vescovo, Impedance measurement to assess microbial contamination of ready-touse vegetables. Zaitschrift für Lebensmitteluntersuchung und - Forschung 205(3), 248-250 (1997)

11. T. Riberio, G. Romestant, J. Depoortere, A. Pauss, Development, validation, and applications of a new laboratory-scale indirect impedancemeter for rapid microbial control. J. Appl. Microbiol. Biot. 63(1), 35-41 (2003)

12. P. Fernández, J.A. Gabaldón, M.J. Periago, Detection and quantification of Alicyclobacillus acidoterrestris by electrical impedance in apple juice. Food Microbiol. 68, 34-40 (2017)

13. F.R. Harker, J. Dunlop (1994) Electrical impedance studies of nectarine during cool storage and fruit ripening. Postharvest. Biol. Techol., (4): 125-134

14. H. Sotoyama, M. Saito, K.-B. Oh, Y. Nemoto, H. Matsuoka, In vivo measurement of the electrical impedance of cell membranes of tobacco cultured cells with a multifunctional microelectrode system. Bioelectrochem. Bioenergy 45, 83-91 (1998)

15. A.D. Bauchot, F.R. Harker, W.M. Arnold (2000) The use of electrical impedance spectroscopy to assess the physiological condition of kiwifruit. Postharvest. Biol. Techol. (18): 9-18

16. A. Figueiredo Neto, N. Cárdenas Olivier, E. Rabelo Cordeiro, H. Pequeno de Oliveira (2017) Determination of mango ripening degree by electrical impedance spectroscopy. Comput. Electron. Agric. (143): 222-226

17. T. Watanabe, Y. Ando, T. Orikasa, S. Kasai, T. Shiina, Electrical impedance estimation for apple fruit tissues during storage using Cole-Cole plots. J. Food Eng. 221, 29-34 (2018)

18. G.J. Gaskin, J.D. Miller (1996) Measurement of soil water content using a simplified impedance measuring technique. J. Agric. Eng. Res. (2): 153-159

19. A. Piccoli, L. Pillon, E. Favaron 1997. Asymmetry of the total body water prediction bias using the impedance index. Nutrition (13): 438-444

20. A. Nakonieczna, B. Paszkowski, A. Wilczek, A. Szypłowska, W. Skierucha (2016) Electrical impedance measurements for detecting artificial chemical additives in liquid food products. Food Control, (66): 116-129

21. R. Żywica, G. Pierzynowska-Korniak, J. Wójcik, Application of food products electrical model parameters for evaluation of apple purée dilution. J. Food Eng. 67, 413-418 (2005)

22. R. Żywica, J.K. Banach (2015) Quality assessment of pomaces received from stone and pome fruits using the electrical properties. Ann. Nutr. Metab. (67): supp.1, 486 
23. PN-EN 12143:2000. Soki owocowe i warzywne - Oznaczanie zawartości substancji rozpuszczalnych metoda refraktometryczną (Fruit and vegetable juices. Determination of soluble matter content by refractometric method)

24. PN-EN 12147:2000. Soki owocowe i warzywne - Oznaczanie kwasowości miareczkowej (Fruit and vegetable juices - Determination of titrable acidity)

25. PN-EN 1131:1999. Soki owocowe i warzywne - Oznaczanie gęstości względnej (Fruit and vegetable juices - Determination of the relative density)

26. PN-EN 1132:1999. Soki owocowe i warzywne - Oznaczanie pH (Fruit and vegetable juices - Determination of the $\mathrm{pH}$-value)

27. M. Krełowska-Kułas, Badanie jakości produktów spożywczych (Quality determination of the food products) (PWE, Warsaw, 1993)

28. PN-EN 12144:1999. Soki owocowe i warzywne - Oznaczanie zawartości popiołu (Fruit and vegetable Juices. Determination of ash)

29. E. Pijanowski, S. Mrożewski, A. Horubała, A. Jarczyk, Technologia produktów owocowych $i$ warzywnych (Technology of fruit and vegetable products), vol. I (PWRiL, Warsaw, 1973) (in Polish)

30. Warsaw, Biofizyka. Podręcznik dla studentów (Biophysics. Textbook for students) (PZWL, Poland, 2008) (in Polish)

31. M. Czerniewicz, R. Żywica, J.K. Banach, The effect of calcium ions level on the quality and electrical properties of raw milk. Pol. J. Comm. Sci. 4(49), 109-116 (2016)
32. R. Żywica, Banach ${ }^{\mathrm{JK}}$., K. Kiełczewska (2012) An attempt of applying the electric al properties for the evaluation of milk fat content of raw milk. J. Food Eng., (111): 420-424

33. J.K. Banach, R. Żywica, I. Nieradko, B. Staniewski (2012) Studies on determination of mathematical relationships between rapeseed oil content and electrical properties of butter and fat mixes. J. Food Eng., (112): 346-351

34. M.F. Mabrook, M.C. Petty (2003). A novel technique for the detection of added water to full fat milk using single frequency admittance measurements. Sens. Actuators B, (96): 215-218

35. M.F. Mabrook, M.C. Petty (2003). Effect of composition on the electrical of milk. J. Food Eng. (60): 321-325

36. J.L. Damez, S. Clerjon (2008) Meat quality assessment using biophysical methods related to meat structure. Meat Sci., (80): 132-149

37. J.L. Damez, S. Clerjon, S. Abouelkaram, J. Lepetit (2007) Dielectric behavior of beef meat in the $1-1500 \mathrm{kHz}$ range: Simulation with the Ficke/Cole-Cole model. Meat Sci., (77): 512-519

Publisher's Note Springer Nature remains neutral with regard to jurisdictional claims in published maps and institutional affiliations. 